\title{
Pengaruh Kebijakan Utang Pada Nilai Perusahaan Dengan Ukuran Perusahaan Sebagai Pemoderasi
}

\author{
I Gusti Agung Trisna Dewi ${ }^{1}$ \\ Maria M. Ratna Sari ${ }^{2}$ \\ ${ }^{1,2}$ Fakultas Ekonomi dan Bisnis Universitas Udayana (Unud), Bali, Indonesia \\ e-mail: gungtik67@gmail.com
}

\begin{abstract}
ABSTRAK
Tujuan dari penelitian ini adalah untuk mengetahui pengaruh kebijakan utang pada nilai perusahaan dan ukuran perusahaan dalam memoderasi pengaruh kebijakan utang terhadap nilai perusahaan. Penelitian ini menggunakan data pada perusahaan food and beverage yang terdaftar di Bursa Efek Indonesia periode 2013-2017. Penentuan sampel dalam penelitian ini menggunakan metode purposive sampling, dengan jumlah pengamatan sebanyak 13 perusahaan. Teknik analisis data yang digunakan adalah Moderate Regression Analysis (MRA) / analisis regresi moderasi. Berdasarkan hasil penelitian, ditemukan bahwa kebijakan utang memiliki pengaruh negatif signifikan terhadap nilai perusahaan dan ukuran perusahaan mampu memoderasi pengaruh kebijakan utang terhadap nilai perusahaan.
\end{abstract}

Kata Kunci: Kebijakan utang, ukuran perusahaan, nilai perusahaan

\begin{abstract}
The purpose of this study was to determine the effect of debt policy on firm value and firm size in moderating the effect of debt policy on firm value. This study uses data on food and beverage companies listed on the Indonesia Stock Exchange for the period 2013-2017. Determination of samples in this study using purposive sampling method, with the number of observations as many as 13 companies. The data analysis technique used is the Moderate Regression Analysis (MRA) / moderation regression analysis. Based on the results of the study, it was found that debt policy had a significant negative effect on firm value and the size of the company was able to moderate the influence of debt policy on firm value.
\end{abstract}

Keywords: Debt policy, company size, company value

\section{PENDAHULUAN}

Tujuan dari suatu perusahaan menurut James C. Van Horne (1974) dalam (Adetunji et al., 2016) adalah untuk memaksimalkan nilai kepada pemegang saham. Nilai dari suatu perusahaan diwakili oleh nilai pasar saham biasa perusahaan, yang merupakan refleksi dari keputusan investasi dan pendanaan perusahaan. Sukirni (2012) menyatakan nilai perusahaan adalah kondisi tertentu yang telah dicapai oleh suatu perusahaan sebagai gambaran dari kepercayaan 
masyarakat terhadap perusahaan setelah melalui proses kegiatan selama beberapa tahun, yaitu sejak perusahaan tersebut didirikan sampai dengan saat ini. Nilai perusahaan merupakan nilai pasar atas surat berharga utang dan ekuitas pemegang saham yang beredar (Keown, 2004 dalam Ariasih \& Yadnyana, 2018).

Pentingnya nilai perusahaan sebagai salah satu persepsi keberhasilan perusahaan. Keberhasilan perusahaan tercermin dari tingginya harga saham. Jadi dapat dikatakan bahwa semakin tinggi harga saham, semakin tinggi pula nilai perusahaan. Nilai perusahaan yang tinggi dapat meningkatkan kesejahteraan para pemegang saham. Nilai perusahaan yang tinggi akan membuat pasar percaya tidak hanya pada kinerja perusahaan saat ini, namun juga pada prospek perusahaan di masa depan Apabila perusahaan dapat memberikan harapan nilai yang besar di masa depan maka perusahaan tersebut akan memperoleh nilai yang tinggi pada saat itu. Namun, sebaliknya jika tidak mampu memberikan gambaran dan harapan yang mantap terhadap nilai (hasilnya) di masa depan, tentu saja akan dinilai rendah oleh masyarakat dan pemegang saham (Orientati, 2014).

Fenomena terpuruknya nilai perusahaan seperti yang dialami PT Tiga Pilar Sejahtera Tbk (AISA). Perusahaan yang berdiri sejak 1992 dan bergerak di industri makanan serta pengelolaan pangan ini menderita rugi bersih sebesar Rp 551,9 miliar di akhir 2017. Hasilnya, banyak investor yang menarik sahamnya dari PT perusahaan ini. PT Tiga Pilar Sejahtera Tbk kesulitan dalam membayar utang yang akan jatuh tempo (kontan.co.id, 2018). Tiga Pilar Sejahtera juga terancam pailit. Dua kreditur Tiga Pilar, PT Sinarmas Asset Management dan PT Asuransi Jiwa Sinarmas MSIG, telah mendaftarkan permohonan Penundaan 
Kewajiban Pembayaran Utang ke Pengadilan Niaga Jakarta Pusat. Permohonan PKPU ini terdaftar dengan nomor perkara 92/Pdt.Sus-PKPU/2018/PN Jkt.Pst (alenia.id, 2018).

Optimalisasi nilai perusahaan merupakan tujuan perusahaan dapat dicapai melalui pelaksanaan fungsi manajemen keuangan, (Suartawan \& Yasa, 2013). Satu kebijakan atau keputusan keuangan yang diambil akan mempengaruhi keputusan keuangan lainnya dan berdampak pada nilai perusahaan (Sukirni, 2012). Perusahaan harus memilih keputusan yang tepat sehingga memungkinkan untuk mencapai hasil yang positif. Salah satu dari keputusan keuangan tersebut adalah kebijakan pendanaan atau kebijakan utang. (Fauzi, 2017) menyatakan, dengan menggunakan pendanaan utang perusahaan diharapkan mampu menghasilkan laba yang maksimal. Sumber pendanaan atau kebijakan utang merupakan tindakan manajemen perusahaan untuk mendanai operasional perusahaan dengan menggunakan modal dari sumber internal maupun eksternal. Sumber pendanaan internal diperoleh dari dalam perusahaan seperti modal sendiri dan laba ditahan sedangkan sumber pendanaan eksternal merupakan dana yang diperoleh dari pihak luar perusahaan seperti bank. Dengan menentukan sumber pendanaan yang tepat dapat memperkecil biaya yang dikeluarkan dan menghindari kerugian (Fauzi, 2017).

Hasil penelitian (Listiadi dan Nainggolan 2014) menunjukkan kebijakan utang (DER) memiliki pengaruh negatif dengan nilai perusahaan. Artinya, semakin tinggi utang maka nilai perusahaan rendah dan sebaliknya, semakin rendah utang maka nilai perusahaan tinggi. Apergis dan Sorros (2011) 
menyatakan bahwa variabel utang obligasi jangka panjang berpengaruh negatif dan signifikan terhadap nilai perusahaan, sedangkan (Lixin \& Lin, 2011) variabel utang jangka pendek (short term borrowing) mempunyai pengaruh negatif dan signifikan terhadap market value of company. (Vieira, 2017) menemukan bahwa utang jangka pendek dan utang jangka panjang berpengaruh negatif pada kinerja perusahaan. Sementara menemukan bahwa Debt to Equity Ratio (DER) tidak berpengaruh terhadap nilai perusahaan. (Kodongo et al., 2014) mengemukakan bahwa leverage tidak berpengaruh pada Tobin's $Q$ (proksi yang digunakan untuk nilai perusahaan). Cortez \& Susanto (2012), Adetunji et al. (2016), (Suta dkk., 2016) menjelaskan penggunaan utang dalam perusahaan tidak memberikan pengaruh yang signifikan pada nilai perusahaan tersebut.

Gamayuni (2015) dan Pratiwi \& Mertha (2017) menemukan kebijakan utang berpengaruh positif signifikan terhadap nilai perusahaan. Sama halnya dengan Chowdhury (2010) yang berpendapat bahwa dengan adanya utang, perusahaan dapat meningkatkan nilai perusahaannya. Perusahaan memperoleh manfaat dari penambahan utang terutama pajak karena biaya bunga atas utang dapat digunakan sebagai pengurang penghasilan kena pajak perusahaan. Sedangkan Sumanti \& Mangantar (2015) menyatakan kebijakan utang tidak berpengaruh signifikan terhadap nilai perusahaan. Penyebabnya adalah informasi perusahaan yang memiliki nilai utang yang tinggi dan kesempatan berinvestasi yang tinggi prospek kedepan berdasarkan teori pesinyalan, tidak mempengaruhi investor. 
Beberapa penelitian sebelumnya, hasilnya masih banyak ditemukan ketidakkonsistenan hasil penelitian sehingga penulis memutuskan untuk menambahkan variabel moderasi. Ukuran perusahaan digunakan sebagai variabel pemoderasi karena investor cenderung lebih tertarik pada perusahaan dengan ukuran yang besar. Penyebabnya adalah perusahaan besar memiliki kemudahan dalam mengakses pasar modal. Investor juga memperhatikan kestabilan perusahaan besar karena manajemen perusahaan besar akan bekerja dengan baik untuk menjaga kondisi perusahaan (Nopiyanti \& Darmayanti, 2016). Kondisi yang stabil tersebut menarik investor untuk memperoleh saham dari perusahaan yang pada akhirnya harga saham mengalami peningkatan. Harga saham yang tinggi merupakan indikator dari tingginya nilai perusahaan.

Hasil penelitian dari Rizqia et al., 2013 menyimpulkan variabel firm size memiliki pengaruh positif dan signifikan terhadap nilai perusahaan yang diproksikan dengan Tobin's Q. Samisi \& Ardiana (2013), (Lumapow \& Tumiwa (2017), Goh \& Simanjuntak (2018) juga menyatakan ukuran perusahaan berpengaruh positif dan signifikan terhadap nilai perusahaan. Penelitian oleh Purnomosidi et al. (2014) mengemukakan bahwa size berpengaruh positif terhadap firm value yaitu Tobin's Q, Price To Book Value (PBV), dan Stock Return (SR). Namun, berdasarkan penelitian dari Siallagan \& Mas Ud, (2006) variabel firm size mempunyai pengaruh negatif dan signifikan terhadap nilai perusahaan. Penelitian dari Setiabudi \& Agustia (2012) menyimpulkan bahwa company size tidak berpengaruh signifikan terhadap firm value. 
Perusahaan manufaktur yang bergerak disektor food and beverage dipilih penelitian ini karena pertumbuhannya semakin pesat dari tahun ke tahun. Menurut catatan Badan Pusat Statistik (BPS) dalam CNN Indonesia, pertumbuhan produksi industri manufaktur besar dan sedang (IBS) sebesar 5,51 persen secara tahunan pada kuartal III 2017. Angka ini dikatakan lebih tinggi dibanding kuartal II/2017 sebesar 3,89 persen dan periode yang sama tahun lalu sebesar 4,87 persen. Kepala BPS Suhariyanto mengatakan, meskipun seluruh sektor industri mengalami perbaikan, namun sektor yang memiliki pengaruh signifikan terhadap pertumbuhan pada kuartal ini adalah industri makanan dan minuman. Hal ini disebabkan makanan dan minuman adalah kebutuhan pokok masyarakat. Investor semakin tertarik untuk menanamkan modalnya pada sektor food and beverage karena prospek yang cukup baik.

Teori keagenan (agency theory) menurut Jensen dan Meckling (1976) mendeskripsikan hubungan agensi mulai muncul ketika satu orang atau lebih (principal) menggunakan orang lain (agent) untuk memberikan jasa dan kemudian mendelegasikan wewenang untuk pengambilan keputusan kepada agent tersebut. Agen menutup kontrak untuk melakukan tugas-tugas tertentu bagi prinsipal kemudian prinsipal menutup kontrak untuk memberi imbalan kepada agen, ibarat pemilik perusahaan dan manajemen perusahaan (Hendriksen dan Michael, 2000).

Dalam manajemen keuangan tujuan utama perusahaan adalah memaksimalkan kemakmuran pemegang saham, harus bertindak untuk kepentingan pemegang saham. Namun dalam kenyataannya, sering terjadi konflik 
keagenan antara manajemen dan pemegang saham yang disebabkan perbedaan kepentingan antara manajemen dan pemegang saham. Masalah keagenan yaitu konflik antara manajer dan pemegang saham dapat diminimumkan dengan suatu mekanisme pengawasan yang dapat mensejajarkan kepentingan-kepentingan tersebut sehingga muncul biaya keagenan (agency cost), (Dewi \& Wirasedana, 2018).

Jensen dan Meckling (1986) menyatakan bahwa agency problem akan terjadi bila proporsi kepemilikan manajer atas saham kurang dari $100 \%$. Oleh karena itu, manajer bertindak untuk mengejar kepentingannya sendiri dan tidak berdasarkan memaksimalkan nilai perusahaan dalam pengambilan keputusan keuangan khususnya keputusan pendanaan. Penambahan utang dalam struktur modal dapat mengurangi penggunaan saham sehingga meminimalisasi biaya keagenan ekuitas. Akan tetapi, perusahaan memiliki kewajiban untuk mengembalikan pinjaman dan membayarkan beban bunga secara periodik. Selain itu penggunaan utang yang terlalu besar juga akan menimbulkan konflik keagenan sehingga memunculkan biaya keagenan utang.

Teori pecking order (Myers, 1984; Myers dan Majluf, 1984) tidak menganjurkan struktur modal yang optimal, tetapi hierarki sumber pendanaan. Brealey and Myers (1991) dalam menyatakan bahwa perusahaan menyukai pendanaan internal dibandingkan dengan eksternal. Apabila dana hasil operasi kurang dari kebutuhan investasi, maka perusahaan akan mengurangi saldo kas atau menjual sekuritas yang dimiliki. Apabila pendanaan dari luar (external financing) diperlukan, maka perusahaan akan menerbitkan sekuritas yang paling 
“aman" terlebih dulu. Yaitu dimulai dengan penerbitan obligasi, kemudian diikutioleh sekuritas yang berkarakteristik opsi (seperti obligasi konversi), baru akhirnya apabila masih belum mencukupi, saham baru diterbitkan.

Pecking order menjelaskan bahwa perusahaan yang lebih menguntungkan memiliki tingkat utang yang lebih rendah, (Vieira, 2017). Penyebabnya bukan karena perusahaan tersebut memiliki rasio utang sasaran rendah tetapi karena mereka tidak memerlukan uang dari luar. Hanya sedikit perusahaan menguntungkan yang menerbitkan utang karena mereka tidak memiliki dana internal yang cukup untuk program investasi modal mereka dan karena utang berada pada urutan pertama dalam urutan pilihan (pecking order) untuk pendanaan eksternal (Myers dan Majluf, 1984).

Sukirni, (2012) menyatakan nilai perusahaan adalah kondisi tertentu yang telah dicapai oleh suatu perusahaan sebagai gambaran dari kepercayaan masyarakat terhadap perusahaan setelah melalui proses kegiatan selama beberapa tahun, yaitu sejak perusahaan tersebut didirikan sampai dengan saat ini. Meningkatnya nilai perusahaan adalah sebuah prestasi, yang sesuai dengan keinginan para pemiliknya, karena dengan meningkatnya nilai perusahaan, maka kesejahteraan para pemilik juga akan meningkat, dan ini merupakan tugas dari manajer sebagai agen yang telah diberi kepercayaan oleh para pemilik perusahaan untuk menjalankan perusahaannya (Bambang, 2010). Nilai perusahaan tercermin dalam harga pasar perusahaan, dan merupakan harga yang harus dibayar ketika perusahaan mengambil alih, (Gamayuni, 2015). 
Menurut Pratiwi (2017) semakin tinggi harga saham maka semakin tinggi pula nilai perusahaan. Nilai perusahaan yang tinggi mengindikasikan semakin tinggi tingkat kemakmuran pemilik saham. Menurut Goh \& Simanjuntak (2018), nilai perusahaan merupakan persepsi investor terhadap tingkat keberhasilan perusahaan yang sering dikaitkan dengan harga saham. Harga saham yang tinggi membuat nilai perusahaan juga tinggi. Nilai perusahaan yang tinggi akan membuat pasar percaya tidak hanya pada kinerja perusahaan saat ini namun juga pada prospek perusahaan di masa depan.

Menurut Fahmi (2013:160), utang adalah kewajiban (liabilities). Artinya utang merupakan kewajiban yang dimiliki oleh pihak perusahaan yang sumbernya dari dana eksternal baik yang berasal dari sumber pinjaman perbankan, leasing, penjualan obligasi dan sejenisnya. Maka, suatu kewajiban adalah mewajibkan bagi perusahaan melaksanakan kewajiban tersebut namun jika kewajiban tersebut tidak dilaksanakan tepat waktu, perusahaan menerima sanksi atau akibat. Sanksi dan akibat yang diperoleh tersebut berupa pemindahan kepemilikan asset pada suatu saat. Utang menunjukan sumber modal yang berasal dari kreditur. Dalam jangka waktu tertentu pihak perusahaan wajib membayar kembali atau wajib memenuhi tagihan yang berasal dari pihak luar tersebut. Pemenuhan kewajiban ini dapat berupa pembayaran uang, penyerahan barang atau jasa kepada pihak yang telah memberikan pinjaman kepada perusahaan.

Untuk memaksimalkan nilai perusahaan dapat dicapai melalui pelaksanaan fungsi manajemen keuangan, dimana satu kebijakan atau keputusan keuangan yang diambil akan mempengaruhi keputusan keuangan lainnya dan berdampak 
pada nilai perusahaan (Sukirni, 2012). Salah satu dari keputusan keuangan yang tersebut adalah kebijakan pendanaan atau kebijakan utang. Sumber pendanaan atau kebijakan utang merupakan tindakan manajemen perusahaan untuk mendanai operasional perusahaan dengan menggunakan modal dari sumber internal maupun eksternal. Sumber pendanaan internal diperoleh dari dalam perusahaan seperti modal sendiri dan laba ditahan sedangkan sumber pendanaan eksternal merupakan dana yang diperoleh dari pihak luar perusahaan seperti bank.

Pecking order menjelaskan mengapa perusahaan yang paling menguntungkan biasanya meminjam lebih sedikit, ini bukan karena mereka memiliki rasio utang sasaran rendah tetapi karena mereka tidak memerlukan uang dari luar. Hanya sedikit perusahaan menguntungkan yang menerbitkan utang karena mereka tidak memiliki dana internal yang cukup untuk program investasi modal mereka dan karena utang berada pada urutan pertama dalam urutan pilihan (pecking order) untuk pendanaan eksternal.

Hasil penelitian Listiadi \& Nainggolan (2014) dan Utami \& Wirasedana (2018) menunjukkan kebijakan utang (DER) memiliki pengaruh negatif dengan nilai perusahaan. Artinya, semakin tinggi utang maka nilai perusahaan rendah dan sebaliknya, semakin rendah utang maka nilai perusahaan tinggi. Menurut Hermuningsih et al. (2010), kebijakan utang tidak berpengaruh terhadap nilai perusahaan. Apergis dan Sorros (2011) menyatakan bahwa variabel utang obligasi jangka panjang berpengaruh negatif dan signifikan terhadap nilai perusahaan, sedangkan Lixin \& Lin (2011), variabel utang jangka pendek (short term 
borrowing) mempunyai pengaruh negatif dan signifikan terhadap market value of company.

Berdasarkan uraian tersebut maka dapat dirumuskan hipotesis penelitian sebagai berikut:

$\mathrm{H}_{1}$ : Kebijakan utang berpengaruh negatif pada nilai perusahaan

Ukuran perusahaan merupakan faktor penting yang mendorong nilai perusahaan Kodongo et al. (2014), Fauzi, (2017) menyatakan, besar atau kecil ukuran perusahaan terkait dengan kemampuan perusahaan dalam mengembalikan pinjaman, sehingga para kreditur menilai perusahaan yang besar akan lebih mudah melakukan pengembalian atas utang tersebut. Semakin besar perusahaan menunjukkan bahwa perusahaan memiliki aset yang besar, sehingga pihak eksternal tidak merasa khawatir dengan jaminan perusahaan tersebut. Dengan demikian ukuran perusahaan berpengaruh positif terhadap kebijakan utang.

Ukuran perusahaan yang diartikan sebagai seberapa besar perusahaan dilihat dari total aset yang dimiliki, perusahaan dengan ukuran besar diasumsikan mampu mendorong nilai perusahaan lebih baik (Arifah \& Wirajaya, 2018). Menurut (Wahidawati, 2002) perusahaan yang besar tentu dapat lebih mudah mengakses pasar modal, karena kemudahan tersebut maka berarti bahwa perusahaan memiliki fleksibilitas dan kemampuan untuk mendapatkan dana. Perusahaan besar memiliki aset yang besar pula, maka pemberi utang akan merasa mudah dalam memperoleh jaminan. Perusahaan besar tidak akan bergantung pada dana dari pihak internal perusahaan karena lebih mudah mendapatkan dana dari pihak eksternal. Ukuran perusahaan yang besar akan memiliki tingkat risiko bisnis 
yang rendah dibandingkan dengan perusahaan yang berukuran kecil, sehingga perusahaan berukuran besar akan mudah mendapatkan kepercayaan dari pihak kreditur (Jogiyanto, 2010) dalam (Fauzi, 2017).

Ukuran perusahaan berpengaruh positif pada nilai perusahaan (Surya \& Wirawati, 2018) Hasil penelitian dari Fatah et al. (2016), Lumapow et al. (2017) dan Goh \& Simanjuntak (2018) menyimpulkan variabel ukuran perusahaan memiliki pengaruh positif dan signifikan terhadap nilai perusahaan. (Samisi \& Ardiana, 2013) juga menyatakan ukuran perusahaan berpengaruh positif dan signifikan terhadap nilai perusahaan. Penelitian oleh (Purnomosidi et al., 2014) size berpengaruh positif terhadap firm value yaitu Tobin's Q, Price To Book Value $(P B V)$, dan Stock Return (SR). Namun, berdasarkan penelitian dari Siallagan \& Mas Ud, (2006) variabel firm size mempunyai pengaruh negatif dan signifikan terhadap nilai perusahaan. Penelitian dari Setiabudi \& Agustia (2012) juga menyimpulkan bahwa company size tidak berpengaruh signifikan terhadap firm value.Berdasarkan uraian tersebut maka dapat dirumuskan hipotesis penelitian sebagai berikut:

$\mathrm{H}_{2}$ : Ukuran perusahaan mampu memoderasi pengaruh kebijakan utang pada nilai perusahaan

\section{METODE PENELITIAN}

Penelitian ini dilakukan pada perusahaan Perusahaan Food and Beverage go public yang terdaftar di Bursa Efek Indonesia (BEI) tahun 2013-2017 dengan mengakses www.idx.co.id. 
Variabel bebas dalam penelitian ini adalah kebijakan utang $\left(\mathrm{X}_{1}\right)$. Variabel terikat dalam penelitian ini adalah nilai perusahaan $(\mathrm{Y})$. Ukuran perusahaan $(\mathrm{Z})$ merupakan variabel moderasi dalam penelitian ini.

Nilai DER diukur dengan rumus sebagai berikut:

$$
\mathrm{DER}=\frac{\text { Total utang }}{\text { Total ekuitas }}
$$

Rumus perhitungan :

Tobin's $Q=\frac{\text { Total Market Value }+ \text { Total Book Value of Liabilities }}{\text { Total Book Value of Assets }}$

Keterangan:

Total Market Value $=$ Harga saham penutupan $\times$ jumlah saham yang beredar Total Book Value Of Liabilities = Utang lancar + utang jangka panjang Total Book Value Of Assets = Total aset

(Fauzi, 2017) dalam penelitiannya menyatakan bahwa untuk mengukur perusahaan (firm size) dapat diukur dengan cara :

Size $=$ Log natural dari total assets

Populasi dalam penelitian ini adalah seluruh perusahaan food and beverage yang terdaftar di Bursa Efek Indonesia periode 2013-2017. Teknik yang digunakan dalam pengambilan sampel menggunakan metode purposive sampling yaitu metode penentuan sampel dengan pertimbangan tertentu dengan menggunakan karakteristik sebagai berikut : 1) Perusahaan food and beverage yang terdaftar di Bursa Efek Indonesia berturut-turut dari tahun 2013-2017. 2) Perusahaan yang menerbitkan laporan keuangannya untuk periode yang berakhir pada 31 Desember, selama periode pengamatan. 3) Ketersediaan dan kelengkapan data selama penelitian. Apabila dalam proses penelitian terdapat perusahaan yang tidak dapat dihitung rasionya, maka akan dikeluarkan. 
Teknik analisis data yang digunakan pada penelitian ini adalah analisis regresi sederhana dan analisis regresi moderasi. Analisis data yang diperoleh dalam penelitian ini akan diolah menggunakan bantuan program aplikasi SPSS versi 20.0. Teknik analisis regresi sederhana digunakan untuk menguji pengaruh kebijakan utang pada nilai perusahaan. Teknik analisis regresi moderasi digunakan untuk menguji variabel moderasi ukuran perusahaan pada hubungan kebijakan utang pada nilai perusahaan.

Persamaan regresi pada penelitian ini adalah:

$\mathrm{Y}=\alpha+\beta 1 \mathrm{X} 1+\mu$

Keterangan:

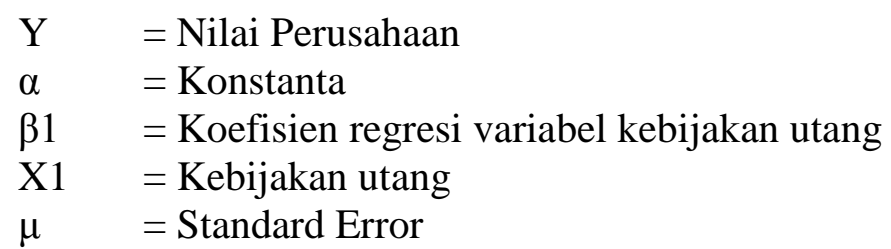

Salah satu cara yang dapat digunakan untuk menguji apakah suatu variabel merupakan variabel moderating yakni dengan melakukan uji interaksi. Uji interaksi antarvariabel disebut dengan Moderated Regression Analysis (MRA), yaitu suatu aplikasi khusus regresi linear berganda dimana dalam persamaan regresinya mengandung unsur interaksi (Ghozali, 2016). Persamaan Moderated Regression Analysis (MRA) sebagai berikut :

$\mathrm{Y}=\alpha+\beta_{1} \mathrm{X}_{1}+\beta_{2} \mathrm{X}_{2}+\beta_{3} \mathrm{X}_{1} \mathrm{X}_{2}+\mathrm{e}$

Keterangan:

$$
\begin{array}{ll}
\mathrm{Y} & =\text { Nilai perusahaan } \\
\alpha & =\text { Konstanta } \\
\beta_{1,} \beta_{2}, \beta_{3} & =\text { Koefisien regresi }
\end{array}
$$




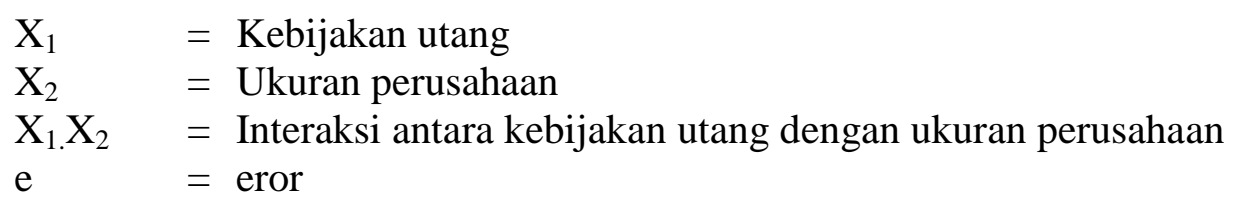

\section{HASIL DAN PEMBAHASAN}

Perusahaan food and beverage yang terdapat di Bursa Efek Indonesia berjumlah 18 perusahaan. Metode pengambilan sampel yang digunakan dalam penelitian ini adalah metode non probability dengan teknik purposive sampling, yaitu teknik penentuan sampel yang dipilih dari populasi yang tersedia dengan menggunakan kriteria yang telah ditentukan sebelumnya. Kriteria pemilihan sampel penelitian ini disajikan pada tabel 1 berikut.

Tabel 1.

Proses Seleksi Sampel Penelitian

\begin{tabular}{|c|c|c|}
\hline No & Kriteria & $\begin{array}{l}\text { Jumlah } \\
\text { Amatan }\end{array}$ \\
\hline 1. & Perusahaan food and beverage yang terdaftar di BEI tahun 2013-2017 & 18 \\
\hline 2. & $\begin{array}{l}\text { Perusahaan food and beverage yang tidak mempublikasikan laporan } \\
\text { keuangan secara konsisten pada tahun 2013-2017. }\end{array}$ & (3) \\
\hline 3. & $\begin{array}{l}\text { Perusahaan food and beverage yang tidak menampilkan data laporan } \\
\text { keuangan yang diperlukan secara lengkap. }\end{array}$ & $(2)$ \\
\hline & Jumlah sampel akhir & 13 \\
\hline & Tahun pengamatan & 5 \\
\hline & Data outlier & (7) \\
\hline & Jumlah pengamatan & 58 \\
\hline
\end{tabular}

Sumber : Data diolah, 2018

Berdasarkan Tabel 1, dapat diketahui bahwa jumlah populasi penelitian yaitu perusahaan food and beverage yang terdaftar di Bursa Efek Indonesia tahun 2013-2017 yaitu sebanyak 18 perusahaan, namun terdapat 3 perusahaan yang tidak mempublikasikan laporan keuangan secara konsisten pada tahun 2013-2017 diantaranya Buyung Poetra Sembada Tbk., Prima Cakrawala Abadi, Tbk., dan Prashida Aneka Niaga Tbk., serta 2 perusahaan yang tidak menampilkan data laporan keuangan yang diperlukan secara lengkap yaitu Campina Ice Cream 
Industry Tbk. dan Sariguna Primatirta Tbk. Untuk mendapatkan model yang lolos uji asumsi klasik, peneliti melakukan outlier data sebanyak 7 data yang menyebabkan pengamatan berkurang menjadi 58 pengamatan. Rincian namanama perusahaan yang dijadikan sampel dalam penelitian ini disajikan pada lampiran 1.

Statistik deskriptif memberikan gambaran umum tentang obyek penelitian yang dijadikan sampel. Statistik deskriptif dalam penelitian ini disajikan untuk menjelaskan karekteristik sampel terutama mencakup nilai minimum, maksimum, mean, dan standar deviasi dari masing-masing variabel. Hasil dari statistik deskriptif tersebut dapat dilihan pada Tabel 2 berikut.

Tabel 2.

Hasil Uji Statistik Deskriptik

\begin{tabular}{lccccc}
\hline Variabel & N & Minimum & Maximum & Mean & $\begin{array}{l}\text { Std. } \\
\text { Deviation }\end{array}$ \\
\hline Kebijakan utang & 58 & 0,06 & 1,77 & 0,9900 & 0,40593 \\
Ukuran Perusahaan & 58 & 26,43 & 32,15 & 28,8747 & 1,49258 \\
Nilai Perusahaan & 58 & 0,00 & 73,89 & 1,8616 & 0,7606 \\
\hline Sur
\end{tabular}

Sumber: Data diolah, 2018

Variabel kebijakan utang menggunakan Debt to Equity Ratio (DER) sebagai proksi memiliki nilai minimum sebesar 0,06 yaitu PT. Multi Bintang Indonesia, Tbk. pada tahun 2015 dan nilai maksimum sebesar 1,77 yang dimiliki oleh PT. Tri Banyan Tirta, Tbk. pada tahun 2013 dengan nilai rata-rata 0,9900. Standar deviasi variabel kebijakan utang sebesar 0,40593. Hal ini menunjukkan bahwa standar penyimpangan data terhadap nilai rata-ratanya sebesar 0,40593 .

Variabel ukuran perusahaan yang diproksikan dengan total aset yang dilogaritmanaturalkan. Nilai terendah (minimum) sebesar 26, 43 yang dimiliki oleh PT. Sekar Laut, Tbk. pada tahun 2013, sedangkan nilai tertinggi (maksimum) 
sebesar 32,15 yang dimiliki oleh PT. Indofood Sukses Makmur, Tbk. pada tahun 2015 dengan niali rata-rata 28,4720. Standar deviasi variabel ukuran perusahaan sebesar 1,49258. Hal ini menunjukkan bahwa standar penyimpangan data terhadap nilai rata-ratanya sebesar 1,49258.

Variabel nilai perusahaan diproksikan dengan Tobin's $Q$. Nilai terendah (minimum) variabel nilai perusahaan adalah 0,00 yang dimiliki oleh PT. Mayora Indah, Tbk. pada tahun 2013, sedangkan nilai tertinggi (maksimum) sebesar 73,89 yang dimiliki oleh PT. Multi Bintang Indonesia, Tbk. pada tahun 2015 dengan nilai rata-rata 1,8616. Standar deviasi variabel nilai perusahaan sebesar 0,74606. Hal ini menunjukkan bahwa standar penyimpangan data terhadap nilai rataratanya sebesar 0,74606 .

Teknik analisis data yang digunakan untuk memecahkan permasalahan penelitian ini adalah analisis Moderated Regression Analysis (MRA). Dalam penelitian ini menggunakan analisis regresi sederhana untuk mengetahui pengaruh kebijakan utang pada nilai perusahaan, serta menggunakan Moderated Regression Analysis untuk menguji kemampuan ukuran perusahana dalam memoderasi pengaruh kebijakan utang pada nilai perusahaan.

Tabel 3.

Hasil Analisis Regresi Linier Berganda

\begin{tabular}{|c|c|c|c|c|c|}
\hline \multirow[b]{2}{*}{ Model } & \multicolumn{2}{|c|}{$\begin{array}{l}\text { Unstandardized } \\
\text { Coefficients }\end{array}$} & \multirow{2}{*}{$\begin{array}{c}\text { Standardized } \\
\text { Coefficients } \\
\text { Beta } \\
\end{array}$} & \multirow[b]{2}{*}{$\mathbf{T}$} & \multirow[b]{2}{*}{ Sig. } \\
\hline & B & $\begin{array}{l}\text { Std. } \\
\text { Error }\end{array}$ & & & \\
\hline $1 \quad$ (Constant) & 8,523 & 3,291 & & 2,589 & 0,012 \\
\hline Kebijakan utang & $-6,728$ & 3,080 & $-0,280$ & $-2,185$ & 0,033 \\
\hline
\end{tabular}

Sumber: Data diolah, 2018 
Tabel 4.

Hasil Uji MRA

\begin{tabular}{|c|c|c|c|c|c|c|}
\hline \multirow{2}{*}{\multicolumn{2}{|c|}{ Model }} & \multicolumn{2}{|c|}{$\begin{array}{l}\text { Unstandardized } \\
\text { Coefficients }\end{array}$} & \multirow{2}{*}{$\begin{array}{c}\begin{array}{c}\text { Standardized } \\
\text { Coefficients }\end{array} \\
\text { Beta }\end{array}$} & \multirow[b]{2}{*}{$\mathrm{T}$} & \multirow[b]{2}{*}{ Sig. } \\
\hline & & B & $\begin{array}{l}\text { Std. } \\
\text { Error }\end{array}$ & & & \\
\hline \multirow[t]{4}{*}{1} & (Constant) & 122,723 & 89,492 & & 1,371 & 0,176 \\
\hline & Kebijakan utang & $-95,189$ & 34,971 & $-3,965$ & $-2,722$ & 0,007 \\
\hline & Ukuran Perusahaan & $-3,926$ & 1,688 & $-0,601$ & $-2,325$ & 0,021 \\
\hline & $\begin{array}{l}\text { Kebijakan utang*Ukuran } \\
\text { perusahaan }\end{array}$ & $-3,050$ & 1,259 & $-3,562$ & $-2,243$ & 0,013 \\
\hline
\end{tabular}

Tabel 3 dan Tabel 4 menunjukkan hasil pengujian dengan regresi MRA pada taraf kesalahan $5 \%(\alpha=0,05)$. Pengujian dilakukan dengan membandingkan tingkat signifikansi (sig) dengan tingkat kesalahan $(\alpha)$. Hasil pengujian regresi menghasilkan model sebagai berikut:

Persamaan Regresi Linear Sederhana (Tabel 4.6):

$$
\mathrm{Y}=8,523+(-6,728 \mathrm{X})
$$

Berdasarkan persamaan diatas, dapat dijelaskan hal-hal sebagai berikut:

Nilai konstanta sebesar 8,523 menunjukkan bahwa jika variabel kebijakan utang sama dengan nol, maka variabel nilai perusahaan akan bernilai sebesar 8,523. Nilai koefisien regresi yakni kebijakan utang (X1) sebesar 6,728 mempunyai hubungan negatif pada nilai perusahaan. Berarti menunjukkan bahwa jika kebijakan utang (X1) meningkat satu satuan, maka akan terjadi penurunan nilai perusahaan (Y) sebesar 6,728 satuan dengan asumsi variabel bebas lainnya dianggap konstan.

Persamaan Moderated Regression Analysis (Tabel 4):

$$
Y=122,723-95,189 X_{1}-3,926 X_{2}-3,050 X_{1} X_{2}
$$


Nilai konstanta sebesar 122,723 menunjukkan bahwa jika variabel kebijakan utang sama dengan nol, maka variabel nilai perusahaan akan bernilai sebesar 122,723

Nilai koefisien regresi kebijakan utang sebesar $-95,189$ menunjukkan bahwa kebijakan utang naik satu satuan, maka nilai perusahaan akan mengalami penurunan sebesar $-95,189$ satuan dengan asumsi variabel lainnya konstan.

Nilai koefisien regresi ukuran perusahaan sebesar 3,926 menunjukkan bahwa bila nilai ukuran perusahaan naik satu satuan, maka nilai perusahaan akan mengalami peningkatan sebesar 3,926 satuan dengan asumsi variabel lainnya konstan.

Nilai koefisien regresi interaksi kebijakan utang dengan ukuran perusahaan sebesar -3,050 menunjukkan bahwa bila interaksi antara kebijakan utang dengan ukuran perusahaan naik satu satuan, maka nilai perusahaan akan mengalami penurunan sebesar -3,050 satuan dengan asumsi variabel lainnya konstan.

Analisis koefisien determinasi digunakan untuk mengukur seberapa jauh kemampuan semua variabel bebas dalam menerangkan variasi dari variabel terikatnya.

Tabel 5.

Hasil Uji Koefisien Determinasi (MRA)

\begin{tabular}{|c|c|c|c|c|c|}
\hline Model & $\mathbf{R}$ & R Square & $\begin{array}{l}\text { Adjusted } \\
\text { Square }\end{array}$ & $\mathbf{R}$ & $\begin{array}{l}\text { Std. Error of the } \\
\text { Estimate }\end{array}$ \\
\hline 1 & $0,280 \mathrm{a}$ & 0,079 & 0,620 & & 9,43868 \\
\hline
\end{tabular}

Hasil pengujian pada persamaan Moderated Regresion Analysis menunjukkan bahwa nilai $\mathrm{R}^{2}$ sebesar 0,620 yang berarti bahwa variabel bebas yang digunakan dalam penelitian ini yakni kebijakan utang memengaruhi variabel 
terikat (nilai perusahaan) dengan variabel pemoderasi (ukuran perusahaan) sebesar $62 \%$ sedangkan $38 \%$ dipengaruhi oleh variabel lainnya yang tidak dimasukkan dalam penelitian ini.

Uji kelayakan model (Uji F) bertujuan untuk apakah model yang digunakan dalam penelitian ini layak atau tidak untuk digunakan sebagai alat analisis dalam menguji pengaruh variabel independen pada variabel dependennya. Adapun hasil dari pengujian kesesuaian model dalam penelitian ini telah disajikan pada tabel 6.

Tabel 6.

Hasil Uji F

\begin{tabular}{llllll}
\hline Model & $\begin{array}{c}\text { Sum of } \\
\text { Squares }\end{array}$ & \multicolumn{1}{c}{ df } & $\begin{array}{c}\text { Mean } \\
\text { Square }\end{array}$ & F & Sig. \\
\hline 1. Regression & 609,061 & 3 & 203,020 & 22,282 & $0,002^{\text {a }}$ \\
$\quad$ Residual & 4805,118 & 54 & 88,984 & & \\
$\quad$ Total & 5414,179 & 57 & & & \\
\hline Sumber: Data diolah, 2018 & & & &
\end{tabular}

Berdasarkan hasil uji kesesuaian model tersebut dapat dilihat bahwa nilai dari uji F sebesar 22,282 dan nilai p-value (Sig. F) yakni 0,002 lebih kecil dari nilai $\alpha=0,05$. Hal ini menunjukkan bahwa model persamaan dalam penelitian ini layak untuk digunakan.

Berdasarkan hasil uji regresi sederhana dan Moderated Regresion Analysis, maka dapat diinterpretasikan hasilnya sebagai berikut:

Hipotesis pertama menyatakan bahwa kebijakan utang berpengaruh negatif pada nilai perusahaan. Hasil perhitungan uji t dapat dilihat pada Tabel 3 yang menunjukkan variabel kebijakan utang memiliki nilai koefisien regresi sebesar 95,189 dengan tingkat signifikansi sebesar 0,007 lebih kecil dibandingkan dengan 
taraf nyata $\alpha=0,05$. Ini menunjukkan bahwa kebijakan utang berpengaruh negatif signifikan terhadap nilai perusahaan, maka hipotesis $\left(\mathrm{H}_{1}\right)$ diterima.

Hipotesis kedua menyatakan bahwa ukuran perusahaan mampu memoderasi pengaruh kebijakan utang pada nilai perusahaan. Hasil perhitungan uji t dapat dilihat pada Tabel 4 yang menunjukkan interaksi antara kebijakan utang dengan ukuran perusahaan memiliki nilai koefisien regresi negatif sebesar -2,423 dengan tingkat signifikansi sebesar 0,013 lebih kecil dibandingkan dengan taraf nyata $\alpha=$ 0,05. Ini menunjukkan bahwa ukuran perusahaan memiliki pengaruh positif signifikan dalam hubungan antara kebijakan utang pada nilai perusahaan dengan kata lain ukuran perusahaan mampu memperkuat pengaruh negatif kebijakan utang pada nilai perusahaan. Ukuran perusahaan dalam penelitian ini termasuk quasi moderator (moderasi semu). Hasil ini mengindikasikan bahwa jika nilai ukuran perusahaan tinggi, maka kebijakan utang akan menurunkan nilai perusahaan.

Hasil analisis regresi menunjukkan bahwa kebijakan utang secara statistik berpengaruh negatif signfikan pada nilai perusahaan $\left(\mathrm{H}_{1}\right.$ diterima). Artinya penggunaan utang dalam perusahaan secara signifikan akan menurunkan nilai perusahaan. Penelitian ini didukung oleh teori pecking order yang menjelaskan bahwa perusahaan yang paling menguntungkan biasanya meminjam lebih sedikit, ini bukan karena mereka memiliki rasio utang sasaran rendah tetapi karena mereka tidak memerlukan uang dari luar (Vieira, 2017).

Hasil penelitian ini sejalan dengan Listiadi \& Nainggolan (2014) dan Utami \& Wirasedana (2018) yang menunjukkan kebijakan utang (DER) memiliki 
pengaruh negatif dengan nilai perusahaan. Apergis \& Sorros (2011) menyatakan bahwa variabel utang obligasi jangka panjang berpengaruh negatif dan signifikan terhadap nilai perusahaan, sedangkan Lixin \& Lin, (2011) variabel utang jangka pendek (short term borrowing) mempunyai pengaruh negatif dan signifikan terhadap market value of company.

Hasil pengujian menunjukkan bahwa ukuran perusahaan secara statistik memiliki pengaruh signifikan dalam mempengaruhi hubungan kebijakan utang pada nilai perusahaan. Artinya semakin tinggi nilai kebijakan utang yang diikuti dengan tingginya nilai ukuran perusahaan, maka akan menurunkan nilai perusahaan. Tingginya nilai ukuran perusahaan dalam artian total aset yang cukup besar membuat perusahaan akan semakin mudah memperoleh sumber pendanaan yang baik dari eksternal (Chi, 2005).

Teori keagenan menjelaskan bahwa penambahan utang untuk menambah modal perusahaan dapat mengurangi penggunaan saham sehingga meniminalisir biaya keagenan ekuitas. Namun, perusahaan akan memiliki kewajiban untuk mengembalikan pinjaman serta bunganya. Peningkatan ukuran perusahaan yang diproksikan dengan total aset menyebabkan perusahaan yang memiliki utang yang cukup tinggi dapat mempengaruhi nilai perusahaan. Semakin besar ukuran perusahaan yang menunjukkan bahwa aset yang dimiliki perusahaan semakin besar dan dana yang dibutuhkan perusahaan untuk mempertahankan kegiatan operasionalnya (Nila \& Suryanawa, 2018).

Perusahaan besar cenderung cukup mudah dalam memperoleh pinjaman dari luar. Penggunaan utang yang kurang tepat dapat meningkatkan risiko 
perusahaan tidak dapat melunasi utang tersebut. Maka dapat dikatakan bila perusahaan besar dengan penggunaan utang yang cukup tinggi dapat menurunkan nilai perusahaan. Hasil penelitian ini didukung oleh penelitian (Rizqia et al., 2013), (Purnomosidi et al., 2014), (Lumapow \& Tumiwa, 2017) dan (Goh \& Simanjuntak, 2018) yang menyatakan ukuran perusahaan mempunyai pengaruh positif dan signifikan terhadap nilai perusahaan.

Penelitian ini menghasilkan simpulan mengenai bagaimana pengaruh kebijakan utang pada nilai perusahaan dengan ukuran perusahaan sebagai pemoderasi. Hasil dari penelitian ini dapat memberikan wawasan terkait nilai perusahaan, kebijakan utang, serta ukuran perusahaan. Penelitian ini didukung oleh teori pecking order yang menyatakan perusahaan yang paling menguntungkan biasanya memiliki utang lebih sedikit karena tidak membutuhkan sumber dana dari luar (Vieira, 2017). Teori keagenan menjelaskan bahwa penambahan utang untuk menambah modal perusahaan dapat mengurangi penggunaan saham sehingga meniminalisir biaya keagenan ekuitas. Namun, perusahaan akan memiliki kewajiban untuk mengembalikan pinjaman serta bunganya. Peningkatan ukuran perusahaan yang diproksikan dengan total aset menyebabkan perusahaan yang memiliki utang yang cukup tinggi dapat mempengaruhi nilai perusahaan.

Penelitian ini diharapkan dapat memberi kontribusi positif bagi semua pihak khususnya pihak investor perusahaan dan perusahaan. Bagi pihak perusahaan agar dapat meminimalisir jumlah utang yang dimiliki sehingga terhindar dari kerugian jika tidak dapat melunasinya. Dampak penggunaan utang 
yang cukup tinggi juga dapat menurunkan nilai perusahaan sehingga keinginan investor untuk menanamkan modal di perusahaan menjadi menurun. Selanjutnya, bagi investor dalam berinvestasi diharapkan memperhatikan jumlah utang dan jumlah aset yang dimiliki perusahaan karena dapat mempengaruhi nilai perusahaan.

\section{SIMPULAN}

Kebijakan utang berpengaruh negatif signifikan pada nilai perusahaan. Semakin tinggi jumlah utang yang dimiliki perusahaan maka nilai perusahaannya akan semakin rendah. Perusahaan yang baik adalah perusahaan yang memiliki jumlah utang yang sedikit karena cenderung tidak memerlukan dana dari luar.

Ukuran perusahaan meningkatkan pengaruh negatif kebijakan utang pada nilai perusahaan. Artinya semakin besar ukuran perusahaan dengan penggunaan utang yang cukup tinggi dapat menurunkan nilai perusahaan.

Peneliti selanjutnya disarankan untuk menambah variabel lain diluar variabel yang telah digunakan seperti profitabilitas, kebijakan dividen, kepemilikan institusional, kepemilikan manajerial, tingkat inflasi, pengungkapan Corporate Social Responsibility dan lain lain. Menambah tahun penelitian serta dapat memilih lokasi penelitian di sektor lain guna melihat pengaruh variabel lainnya terhadap nilai perusahaan.

Berdasarkan hasil penelitian yang menunjukkan bahwa kebijakan utang berpengaruh negatif signifikan pada nilai perusahaan, manajemen perusahaan 
disarankan agar lebih berhati-hati dalam membuat keputusan pendanaan atau kebijakan untuk menambah modal dari pihak eksternal perusahaan.

Penelitian menunjukkan bahwa variabel kebijakan utang berpengaruh negatif signfikan pada nilai perusahaan, sehingga investor diharapkan lebih memperhatikan faktor tersebut sebagai dasar pertimbangan dalam mengambil keputusan investasi.

\section{REFERENSI}

Adetunji, A., State, O., Akinyemi, A., State, I. O., Rasheed, O., \& State, I. O. (2016). Financial leverage and firms' value: a study of selected firms in nigeria, 4(1), 14-32.

Apergis, P. N. (2011). Review of Economics \& Finance Long-Term Debt and the Value of the Firm : Evidence from International Listed Manufacturing Firms, (1988), 60-72.

Ariasih, N. P. D., \& Yadnyana, I. K. (2018). Pengaruh Profitabilitas pada Nilai Perusahaan dengan Corporate Social Responsibility Sebagai Variabel Moderasi, 22, 1600-1625.

Arifah, E. (2018). Pengaruh Pengungkapan ERM terhadap Nilai Perusahaandengan Ukuran Perusahaan, Leverage dan Profitabilitas sebagai Variabel Kontrol Fakultas Ekonomi dan Bisnis Universitas Udayana ( Unud ), Bali , 25, 1607-1633.

Bambang, S. (2010). Peran Kinerja Perusahaan dalam Menentukan Pengaruh Faktor Fundamental Makro Ekonomi, Risiko Sistematis, dan Kebijakan Perusahaan Terhadap Nilai Perusahaan.

Chi, J. D. (2005). Understanding The Endogeneity Between Firm Value with Capital Structure as the Mediator and Firm Size and Industry as Moderators.

Cortez, M. A., Asia, R., Susanto, S., \& Asia, R. (2012). The Determinants Of Corporate Capital Structure: Evidence from Japanese Manufacturing Companies 11(3), 121-135.

Dewi, L. P. U. K., \& Wirasedana, I. W. P. (2018). Pengaruh Keputusan Investasi, Keputusan Pendanaan, Kebijakan Dividen dan Tingkat Inflasi Terhadap 
Nilai Perusahaan. Dewi, L. P. U. K., \& Wirasedana, I. W. P. (2018). Pengaruh Keputusan Investasi, Keputusan Pendanaan, Kebijakan Dividen Dan Tingkat Inflasi Terhadap Nilai Perusahaan, 23, 1736-1764., 23, 17361764.

Fahmi, I. (2013). Pengantar Manajemen Keuangan Teori dan Soal Jawaban Cetakan Kedua. Bandung: Alfabeta.

Fatah, D., Amboningtyas, D., Fathoni, A., Turnover, T. A., Turnover, T. A., Turnover, T. A., ... Turnover, T. A. (2016). Analysis of Effect of Capital Structure, Liqudity, Profitability, Total Assets Turnover and Firm Size to the Value of Companies.

Fauzi, I. R. (2017). Pengaruh Kepemilikan Manajerial, Ukuran Perusahaan, Kebijakan Dividen dan Profitabilitas terhadap Kebijakan Hutang.

Gamayuni, R. R. (2015). The Effect Of Intangible Asset, Financial Performance And Financial Policies On The Firm Value, 4(1), 202-212.

Goh, T. S. (2018). The Influence of Firm Size , Export Ratio and Earning Variablity On Firm Value with Economic Exposure as Intervening Variable in The Manufacturing Industry Sector, (January). https://doi.org/10.2991/ebic-17.2018.82

Hermuningsih, S., Agus Harjito, D., \& KusumaWardani, D. (2010). The Influence Of Insider Ownership, Deviden Policy And Debt Policy To The Firm Value At Companies Which Are Enlisted In Indonesia Stock Exchange. Proceeding International Conference on Business and Economics (ICBE), 1(1), 1-10.

Horizons, E., Chowdhury, A., \& Chowdhury, S. P. (2010). Impact of capital structure on firm 's value : Evidence from Bangladesh.

Kodongo, O., Mokoteli, T. M., \& Maina, L. (2014). Capital structure, profitability and firm value: panel evidence of listed firms in Kenya, (57116).

Listiadi, A. (2014). Subaraman Desmon Asa Nainggolan dan Agung Listiadi; Pengaruh Kebijakan Hutang ..., 2.

Lixin, X., \& Lin, C. (2011). The Relationship Between Debt Financing and Market Value of Company: Empirical Study of Listed Real Estate Company of China 2 Advantages and Disadvantages of Debt Financing, 2043-2047.

Lumapow, L. S., Arthur, R., Tumiwa, F., \& Faculty, E. (2017). The Effect of Dividend Policy , Firm Size , and Productivity to The Firm Value, 8(22), 20 24. 
Ngr, I. G., Adi, P., \& Yasa, G. W. (2013). Pengaruh Investment Opportunity Set dan Free Cash Flow pada Kebijakan Dividen dan Nilai Perusahaan , 63-74.

Nila, L., \& Suryanawa, I. K. (2018). Pengaruh Profitabilitas dan Ukuran Perusahaan Terhadap Nilai Perusahaan dengan Pengungkapan Corporate Social Responsibility Sebagai Pemoderasi, 23, 2145-2174.

Nopiyanti, I. D. A., \& Darmayanti, N. P. A. (2016). Pengaruh PER, Ukuran Perusahaan, dan Profitabilitas pada Nilai Perusahaan dengan Struktur Modal sebagai Variabel Moderasi, 5(12), 7868-7898.

Orientati, S. (2014). Pengaruh Hutang terhadap Nilai Perusahaan dengan Ukuran Perusahaan Sebagai Variabel Moderasi.

Pratiwi, N. I. (2017). Pengaruh Ukuran Perusahaan, Kebijakan Hutang, dan Kebijakan Dividen terhadap Nilai Perusahaan pada Perusahaan Manufaktur yang Listing di Bursa Efek Indonesia, 4(2).

Pratiwi, N. P. D., \& Mertha, M. (2017). Pengaruh Kebijakan Hutang dan Profitabilitas pada Nilai Perusahaan dengan Kebijakan Dividen sebagai Variabel Pemoderasi, 20, 1446-1475.

Purnomosidi, L., Suhadak, Hermanto, S., \& Dzulkirom, M. (2014). The Influence of Company Size, Capital Structure, Good Corporate Governance, Infaltion, Interest Rate, and Exchange Rate of Financial Performance and Value of the Company, 26-33.

Rizqia, D. A., Aisjah, S., \& Sumiati. (2013). Effect of Managerial Ownership , Financial Leverage, Profitability , Firm Size , and Investment Opportunity on Dividend Policy and Firm Value, 4(11), 120-130.

Samisi, K., \& Ardiana, P. A. (2013). Pengaruh struktur pendanaan terhadap nilai perusahaan dengan kepemilikan manajerial sebagai variabel moderasi, 2, 451-469.

Setiabudi, A., \& Agustia, D. (2012). Fundamental Factor of Firm due to the Firm Value, 2(12), 12651-12659.

Siallagan, H., \& Mas Ud, M. (2006). Mekanisme Corporate Governance, Kualitas Laba Dan Nilai Perusahaan, (61), 23-26.

Sukirni, D. (2012). Kepemilikan Manajerial, Kepemilikan Institusional, Kebijakan Dividen dan Kebijakan Hutang Analisis terhadap Nilai Perusahaan, 1(2). 
Sumanti, J. C., \& Mangantar, M. (2015). Analisis Kepemilikan Manajerial, Kebijakan Hutang dan Profitabilitas terhadap Kebijakan Dividen dan Nilai Perusahaan pada Perusahaan Manufaktur yang Terdaftar di BEI, 3(1), 11411151.

Surya, D., Dwi, N., Gusti, N., \& Wirawati, P. (2018). Pengaruh Ukuran Perusahaan dan Pengungkapan CSR Terhadap Nilai Perusahaan dengan GCG Sebagai Variabel Pemoderasi Fakultas Ekonomi dan Bisnis Universitas Udayana ( Unud ), Bali , Indonesia, 23, 1386-1414.

Suta, I. W. P., Agustina, P. A. A., \& Sugiarta, I. N. (2016). Pengaruh Kebijakan Hutang pada Nilai Perusahaan dengan Kepemilikan Institusional sebagai Variabel Moderasi, 12(3), 173-185.

Utami, P. P., \& Wirasedana, I. W. P. (2018). Pertumbuhan Penjualan Memoderasi Kebijakan Utang pada Nilai Perusahaan Food and Beverages di BEI Periode 2013-2016.

Vieira, E. S. (2017). Debt policy and firm performance of family firms: the impact of economic adversity. https://doi.org/10.1108/IJMF-03-2016-0062.

Wahidawati. (2002). Kepemilikan Manajerial dan Agency Conflict: Analisis Persamaan Simultan Non Linier dari Kepemilikan Manajerial, Penerimaan Resiko (Risk Taking), Kebijakan Utang dan Kebijakan Dividen. 